Acta vet. scand. 1967, 8, 291-300.

From the Department of Animal Nutrition, Genetics and Hygiene, Royal Veterinary College, Stockholm, Sweden.

\title{
THE GENETIC SEX \\ OF TWO INTERSEXUAL HORSES \\ AND SOME NOTES ON THE KARYOTYPE \\ OF NORMAL HORSES
}

By

Set Bornstein

Different types of intersexuality have been described in the common domestic animals (Overzier 1963). However, these cases have not been the object of such intensive studies as equivalent conditions in man. Thus there is a need for further research on intersexuality in animals. Such investigations also have a great comparative value.

Sporadic cases of intersexuality among horses have been described in the literature (Krediet 1938; Franz \& Widmaier 1960). The frequency in horses should be much lower than in goats and pigs. Krediet found a total of 17 cases reported in the literature from 1909 to 1938. Many of these have incomplete descriptions. Levens (1911) examined 15 foals with defectively developed sexual organs, that were sired from the same stallion but with different mares. In these observations the author used terms such as male-like pseudohermaphrodites (pseudohermaphroditismus masculinus externus) from Kitts system. All had marked stallion behaviour, erection in the stunted penis or enlarged clitoris. Spermatozoa occurred in the testicles in some cases. Krediet described a horse with ovario-testis. He found tubuli with variable width, covered by small light cells on histologic examination of gonads. These sometimes contained a round concrement, that was not further described. A follicle with a degenerated oocyte was found in the left gonad. In most of the above mentioned cases, horse-intersexes had female-like internal sexual organs. Exceptional individuals also had small, stunted 
testicles in the abdominal cavity. Williams (1943) found a case with small undeveloped testicles in a small pocketlike scrotum. Intersexes have often shown stallion behaviour similar to that seen in cryptorchids. All have had an enlarged clitoris. Freudenberg (1960) described what he called a hormone determined female-like intersexual foal that was born twin with a male. Both were delivered stillborn. The ovaries were hypoplastic, the tubular system undifferentiated, and the left gubernaculum Hunteri developed as in females. The placenta was not examined, and thus an occurrence of anastomoses between the foetuses could not be determined. Keller (1934) examined twin horse foetuses in the 7 th month of pregnancy and found vascular anastomoses in chorion.

With the help of a relatively simple screening test one can show the correlation between the appearance and position of chromatin bodies in the cell and the genetic sex. This test concerns the sex-chromatin ("Barr bodies") in interphase nuclei (covered by Overzier; Armstrong \& Marshall 1964) and "drumsticks" in the polymorphonuclear leucocyte (covered by Overzier). This means that the number of bodies in the cell nucleus reflects the number of $\mathrm{X}$-chromosomes in the chromosome complement of the cell.

Two horses of intersex type were examined during the years 1964-65, a foal of Ardent breed and a horse of North Swedish breed.

\section{CASUISTICS}

Case I. This was a 1 year old foal which had a normal body conformation with female-like exterior sex organs. The clitoris was enlarged with a phallus of about $7 \mathrm{~cm}$ length protruding from the ventral part of the vulva (Fig. 1). The urethra ended dorsally (hypospadia). The internal sex organs consisted of a uterus and two hypoplastic testicles.

Case II was a 1/2 year old horse of the North Swedish breed. The body measurements are in agreement with those of North Swedish mares (Dyrendahl 1966): Shoulder height $155.5 \mathrm{~cm}$, chest circumference $185 \mathrm{~cm}$, carpus circumference $34 \mathrm{~cm}$, carpus breadth $5.4 \mathrm{~cm}$.

This horse had a penis-like organ and showed marked stallion behaviour. It mounted mares in heat, developed erection and ejaculated a slimy, waterish fluid which contained no sperma- 


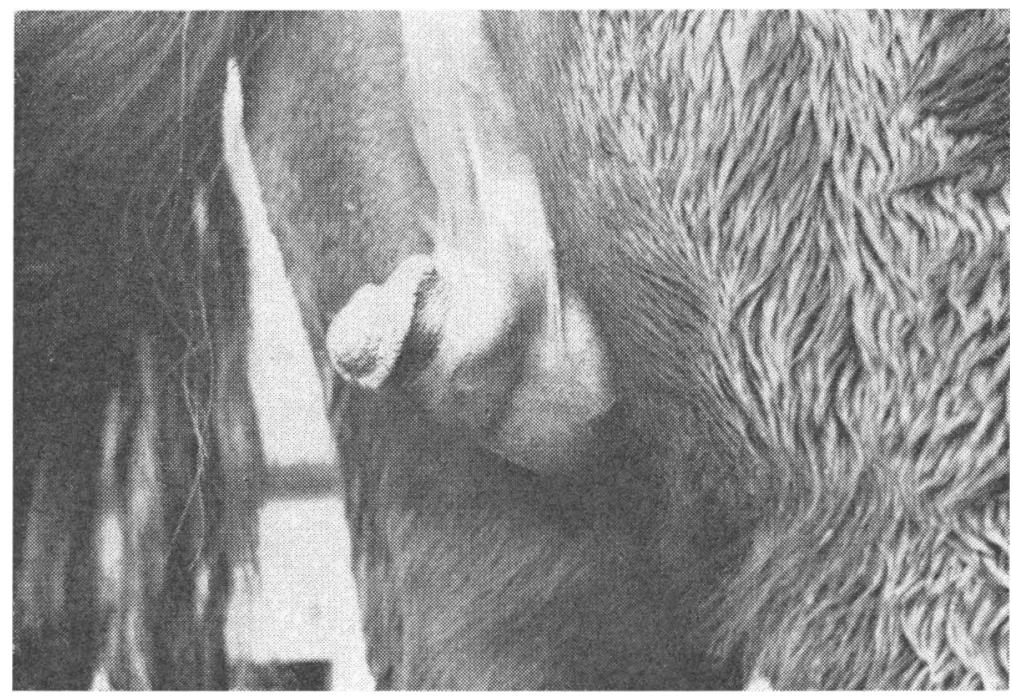

Figure 1. Enlarged clitoris of an intersexual horse (case I).

tozoa. A uterus and 2 hypoplastic testicles were found in the abdomen.

A more detailed clinical and anatomical description will be presented separately.

\section{MATERIAL AND METHODS}

Skin was cultured from both horses for chromosome studies. At the time of slaughter, cells were cultured from a number of tissues from case II, but for technical reasons only cell cultures from the Müllerian duct were successful. For comparative studies of normal complements, skin cells were cultured from 3 mares and 1 stallion. All tissues were cultured according to the method described by Basrur et al. (1963).

Blood smears were prepared for the examination of "drumsticks" from both intersexes, 2 normal mares, and 2 normal stallions. Smears were stained with Tetrachrome-MacNeal, except for the smears from case I which were stained according to Pappenheim (May-Grünwald, Giemsa).

\section{RESULTS}

Both intersexual horses showed the normal karyotype for mares (Sasaki \& Sasaki 1962; Benirschke et al. 1962; Trujillo et al. 1962; Sasaki \& Makino 1962). Most of the examined cells 


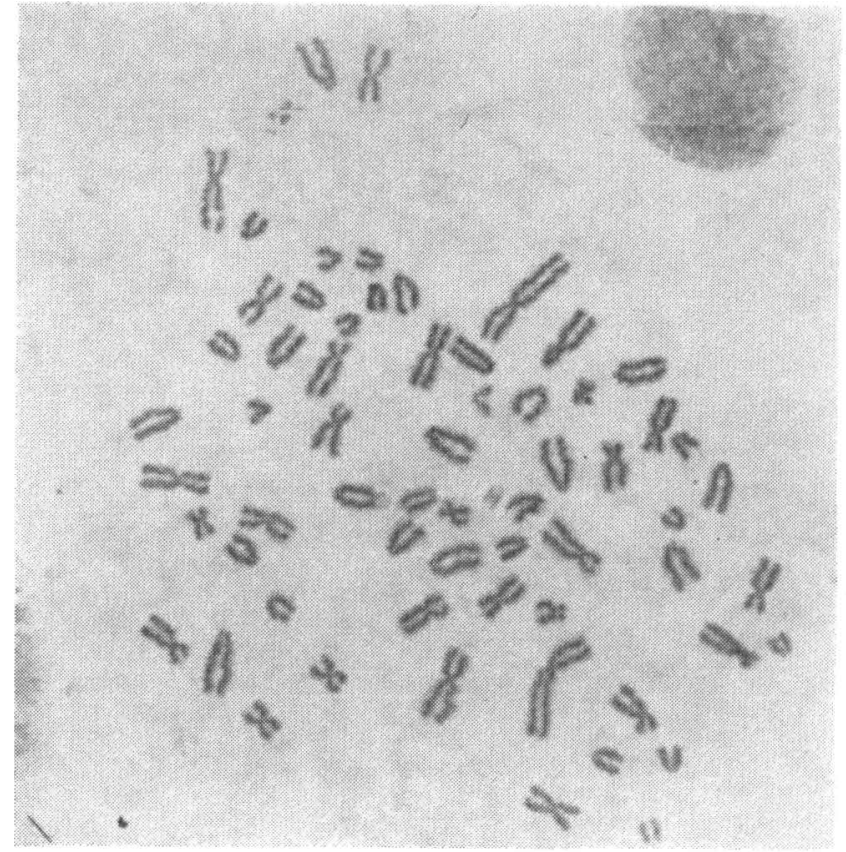
A
$3 y$
$\times \mathbf{x}$

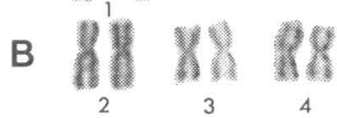

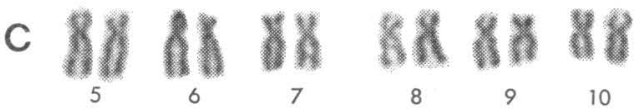

D 2848 औ 8

$\begin{array}{lll}11 & 12 & 13\end{array}$

\section{ADOAOBOAOABOAOOAOO}

E 14

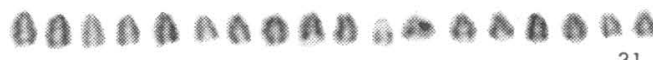

$10 \mathrm{u}$

F i g u r e 2. Metaphase and karyogram from case I. 

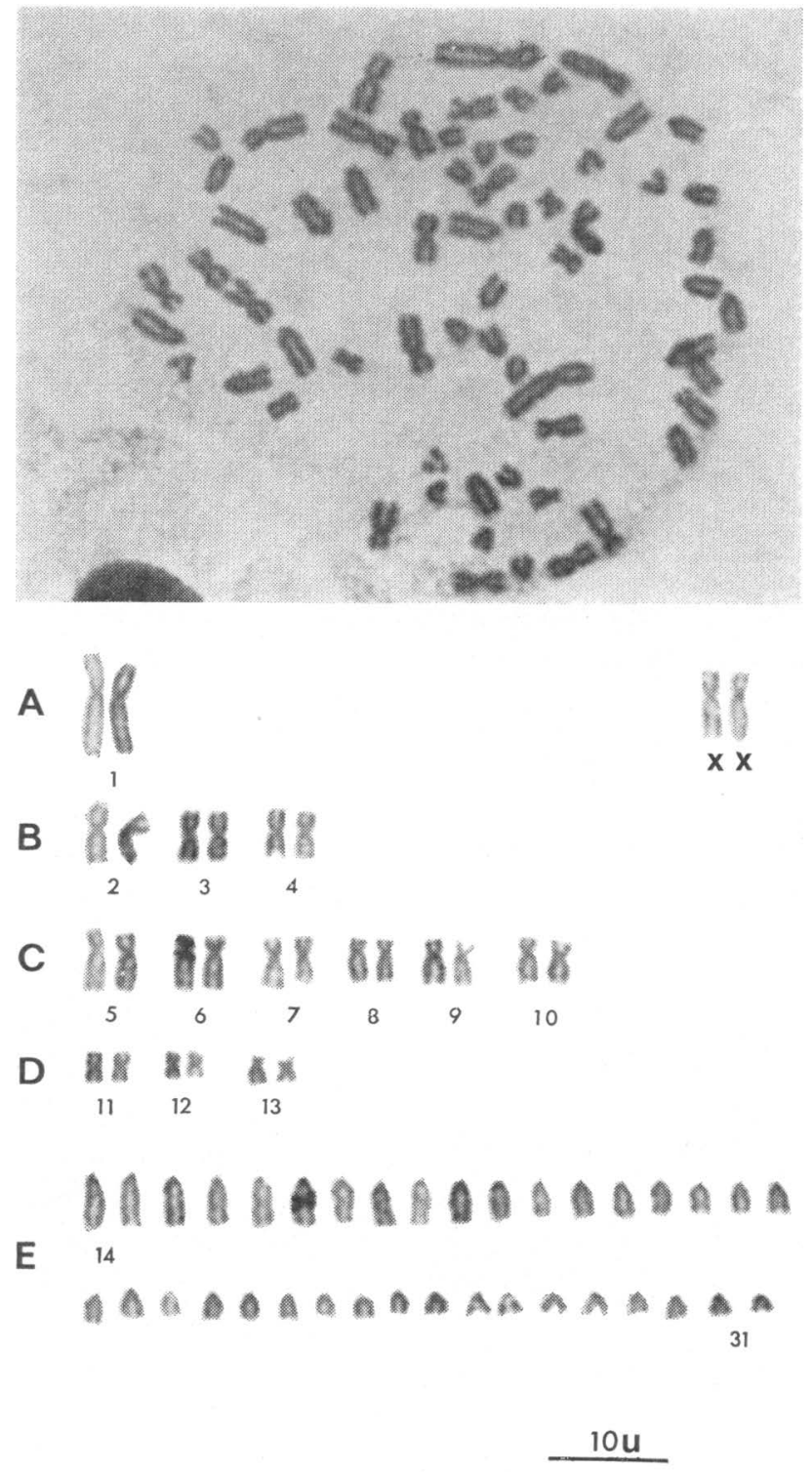

F i g u r e 3. Metaphase and karyogram from case II.

(Table 1) contained 64 chromosomes, 62 of which were autosomes of different appearance and the remaining 2 were the paired sex-chromosome XX.

The chromosomes have been grouped according to the following system (Figs. 2 and 3 ). 
Group A large submetacentric chromosomes

Group B large metacentric chromosomes

Group C medium large submetacentric chromosomes

Group D small metacentric chromosomes

Group E telocentric and/or acrocentric chromosomes

Group A consists of the largest pair which is submetacentric and is clearly separated from the other pairs (no. 1). The next largest submetacentric pair is $\mathrm{XX}$.

Group B consists of 3 pairs. B2 is metacentric and clearly separated from the 2 other pairs. B3 and B4 are also metacentric, smaller than B2, and difficult to distinguish from one another.

To Group C there belong 6 submetacentric pairs. C5 and C6 have the same size and order as B2. It is impossible to separate them. C7 is smaller, and in addition the short arms are relatively longer than the short arms of C5 and C6. C8 and C9 are somewhat smaller than $\mathrm{C7}$, and they generally resemble $\mathrm{C5}$ and $\mathrm{C6}$. It is impossible to distinguish between them. With difficulty $\mathrm{C10}$ can be separated from $\mathrm{B} 4$, but one needs very good plates.

In Group D, there are 3 pairs, about half the size of those in the Groups $A-C$. D11 and D12 are metacentric and can only be distinguished from D13 in good metaphase plates. The latter pair, D13, often looks submetacentric.

In Group E, the remaining autosomes are placed according to decreasing sizes E14-E31. It is impossible to separate them. All are telocentric. One or 2 of the smaller pairs may have (eventually got) a little acrocentric arm, but the appearance of this varies in different preparations. However, in the metaphase plates which were examined, the $3 \mathrm{rd}$ or 4 th smallest pair is easily distinguished (see Fig. 2). The distal part of the arm in this pair is strongly positive heterochromatic and the rest of the arm including the centromere region is negative heterochromatic.

Table 1. Distribution of analysed metaphases of 2 intersex horses.

\begin{tabular}{|c|c|c|c|c|c|c|c|c|c|c|}
\hline & \multicolumn{9}{|c|}{ No. of chromosomes } & \multirow{2}{*}{$\begin{array}{l}\text { No. of } \\
\text { analysed } \\
\text { cells }\end{array}$} \\
\hline & 59 & 60 & 61 & 62 & 63 & 64 & 65 & 66 & 67 & \\
\hline Case I: skin & & 1 & 1 & 1 & 1 & 12 & 1 & 2 & & 19 \\
\hline $\begin{aligned} \text { Case II: } & \text { skin } \\
& \text { Müllerian }\end{aligned}$ & 1 & 1 & 1 & 2 & 2 & 38 & 2 & & 1 & 47 \\
\hline
\end{tabular}




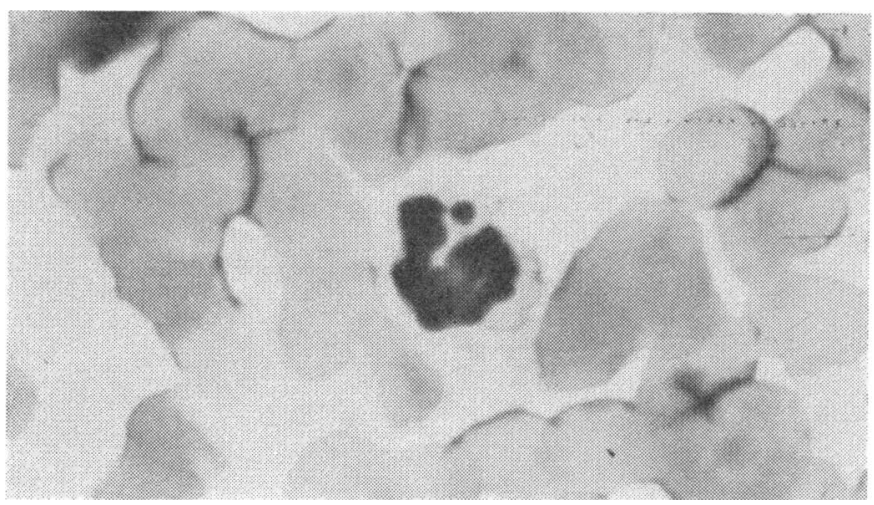

F i g u r e 4. Drumstick in a polymorphonuclear leucocyte from case I.

Of 47 counted metaphase plates from the skin cells of case II, $38(80 \%)$ proved to have 64 chromosomes and clearly distinguishable XX. The distribution can be seen in Table 1. The cells cultivated from the Müllerian duct gave only 33 for complete analysis. Of these, 26 cells had normal female karyotype (distribution, see Table 1 ).

The chromosome complement of case $I$ was in agreement with case II, but too few metaphase plates were available for a reliable

T a b l e 2. Distribution of different types of accessory nuclear lobuli in polymorphonuclear leucocytes. $\mathbf{N}=$ cells without accessory lobules. $\mathrm{Dr}=$ cells with drumsticks. Sess. $=$ cells with sessile nodules. Sm. clubs $=$ cells with small clubs. $a, b$ and $c=$ different countings.

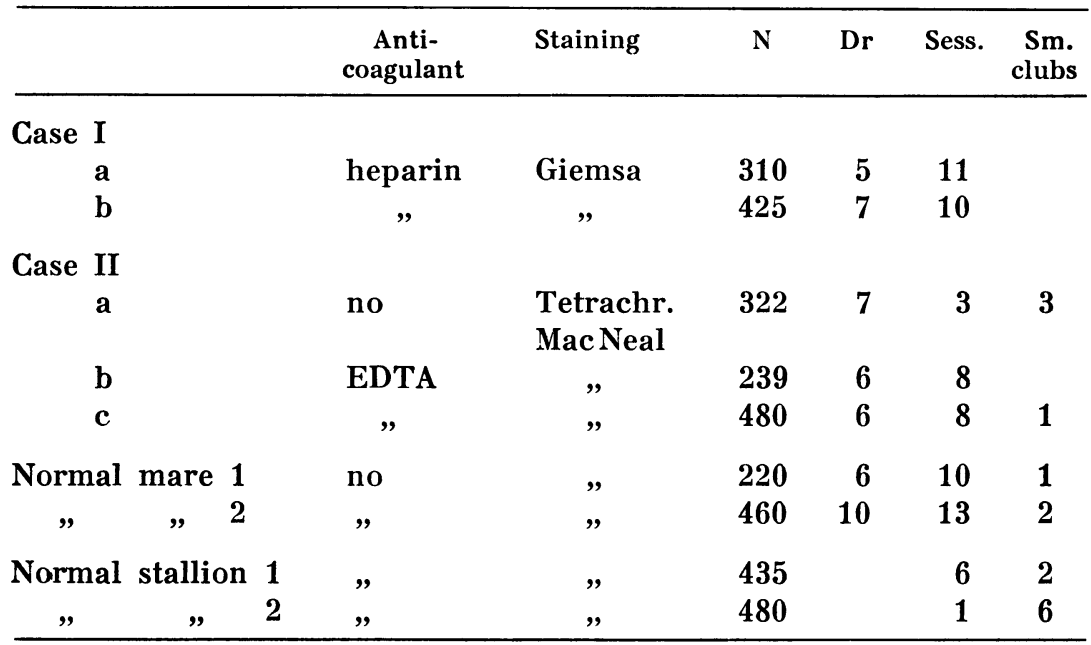


analysis of the complement (see Table 1). Fig. 2 shows a metaphase plate from case I together with the corresponding karyogram. From a total of 19 plates, 12 had completely normal female karyotype.

The examination of drumsticks in neutrophils including both nuclei-segmented and stalk-formed cells showed a female-like picture (see Table 2, Fig. 4) for the 2 horses under discussion. Similar studies were made on 2 normal mares and 2 stallions. No drumsticks were found in the stallions. The frequencies of drumsticks in the mares were variable. However, all had at least 6 drumsticks in each count of less than 500 cells. This is in agreement with that found in a female. The frequency of "small clubs" among stallions in our material was greater than among mares, and the frequency of pseudo-drumsticks and other "accessory nuclear tubules" with various appearance was higher among mares than among stallions.

\section{DISCUSSION}

Certain difficulties are encountered in the identification of the X-chromosomes. Most authors propose 1 of the 2 largest metacentric chromosome pairs (Sasaki \& Sasaki 1962). According to our opinion, $\mathrm{XX}$ belong to the next largest chromosome pair of the complement. This is in agreement with Trujillo et al. (1962).

The drumsticks considered in our material agree concerning appearance and size with those reported in the literature, Davidson \& Smith (1954) in man, and Zaoralek (1959), Rentsch et al. (1960), Colby \& Calhoun (1963) in other animals.

There seem to be divergent opinions as to the number of bloodcorpuscles required for a sex diagnosis. Some authors always evaluate 500 polymorphonuclear neutrophils. Others count only until 6 drumsticks are found for a female diagnosis or 500 cells without drumsticks for a conclusive diagnosis of male sex (Colby \& Calhoun).

Most of the writers count only polymorphonuclear cells. Zaoralek distinguished between granular formed and non-granular formed cells, and found the frequency of drumsticks among mares to be the same for both of the cell-types.

The intersexual condition in the 2 horses examined had a normal female karyotype as has been found in pigs and goats. 
The possibility of a mosaicism cannot be excluded. Most probably the disturbed sexual differentiation is caused by defects on the gene level.

\section{REFERENCES}

Armstrong, C. N. \& A. J. Marshall: Intersexuality in Vertebrates including Man. Academic Press, London and New York 1964, $479 \mathrm{pp}$.

Basrur, P. K., V. R. Basrur \& J. P. W. Gilman: A simple method for short term cultures from small biopsies. Exp. Cell Res. 1963, 30, $229-232$.

Benirschke, K., L. E. Brownhill \& M. M. Beath: Somatic chromosomes of the horse, the donkey and their hybrids, the mule and hinny. J. Reprod. Fertil. 1962, 4, 319-326.

Colby, Ester B. \& L. Calhoun: Accessory nuclear lobule on the polymorphonuclear neutrophil leucocytes of domestic animals. Acta cytol. $1963,7,346-350$.

Davidson, W. M. \& D. L. Smith: Sex differences in the polymorphonuclear leucocytes. Brit. med. J. 1954, 2, 6-7.

Dyrendahl, S.: Personal communication 1966.

Franz, W. \& R. Widmaier: Ein intersexuelles kernmorphologisches Pferd. Berl. Münch. tierärztl. Wschr. 1960, 73, 341-345.

Freudenberg, $F .:$ Intersexuelle Genitalmissbildung beim Stutfohlen eines zweigeschlechtlichen Zwillingpaares. Dtsch. tierärztl. Wschr. 1960, 67, $214-216$.

Keller, K.: Plazentargefässanastomose bei Pferdezwillingen verschiedenen Geschlechts. Z. Tierzücht. Zücht.-Biol. 1934, 30, 241-253.

Krediet, G.: Ovariotestes bei einem Pferd. Acta neerl. Morph. 1938, 2, $62-70$.

Levens, H.: Einige Fälle von Pseudohermaphroditismus beim Pferd. Mh. prakt. Tierheilk. 1911, 22, 267—273.

Overzier, C.: Intersexuality. Academic Press, London and New York 1963, $563 \mathrm{pp}$.

Rentsch, K. J., G. Brüschke \& F. H. Schulz: Uber morphologische Geschlechtsunterschiede an den Kernen von neutrophilen Granulozyten bei Tieren. Dtsch. Gesundh.-Wes. 1960, 15, 240_243.

Sasaki, M. S. \& M. Makino: Revised study of the chromosomes of domestic cattle and the horse. J. Hered. 1962, 53, 157-162.

Sasaki, M. S. \& M. Sasaki: Changes of somatic chromosomes of the horse in serial in vitro transfers. Cytogenetics 1962, 1, 291-300.

Trujillo, J. M., C. Stenius, L. Christian \& S. Ohno: Chromosomes of the horse, the donkey and the mule. Chromosoma (Berl.) 1962, 13, 243 - 248.

Williams, W. L.: Diseases of genital organs of domestic animals. Ithaca, New York 1943, 650 pp.

Zaoralek, P. E.: Die Geschlechtsdiagnose an den neutrophilen Leukozyten des Pferdes. Schweiz. Arch. Tierheilk. 1959, 101, 502-508. 


\section{SUMMARY}

Two intersex horses were characterized externally by vulva and "enlarged clitoris-hypoplastic penis" and internally by uterus and testicles. Both had a normal female karyotype 64/XX. One of the horses whose body measurements were in accordance with mares of the same breed, showed a distinct stallion behaviour.

\section{ZUSAMMENFASSUNG}

Das genetische Geschlecht von zwei Hermaphroditpferden und einige Bemerkungen am Karyotyp normaler Pferde.

Zwei Hermaphroditpferde hatten einen scheinbar normalen weiblichen Karyotypus, 64/XX. Sie hatten Wulva und vergrössten Clitoris hypoplastischen Penis. In der Bauchhöhle wurden Uterus und hypoplastische Hoden angetroffen. Ein der Pferden, dessen äussere Körpermasse mit Stuten derselben Rasse vergleichbar waren, hatte ein Sexualverhalten wie ein Hengst.

\section{SAMMANFATTNING}

Genetiska könet hos två hermafrodithästar samt några kommentarer till normala karyotypen hos häst.

Två hermafrodithästar hade till synes normal honlig karyotyp, $64 / \mathrm{XX}$. De hade vulva och förstorad klitoris-hypoplastisk penis samt uterus och testiklar i bukhålan. En av hästarna, vars exteriöra mått överensstämde med ston inom rasen, hade ett sexuellt beteende som en hingst. 